\title{
Reese-Ellsworth Classification VB
}

National Cancer Institute

\section{Source}

National Cancer Institute. Reese-Ellsworth Classification VB. NCI Thesaurus. Code

C123377.

Vitreous seeding. 